\title{
Global finance and the development of regional clusters: tracing paths in Munich's film and TV industry
}

\author{
Hans-Martin Zademach*
}

\begin{abstract}
Recent work in economic geography has provided notable insights into the regional implications of finance-driven capitalism. In particular, it has been argued that the pressures created by the prioritisation of shareholder value and the rise of new financial agents, such as private equity and hedge funds, are disembedding regional social relations, and empirical evidence illustrates the devastating effects that the short-term profit orientation of these agents can have on local economic development. The relationship between a local economy's integration into the global capitalist system and its development performance is, however, more ambiguous than might be expected. This article explores this connection in greater detail within the context of a regional cluster, namely the film and TV industry cluster in Munich-one of the leading centres for this type of industry in Germany-by means of addressing the adjustments related to the entry of foreign investors after the insolvency of the Kirch Group in 2002. Initially, the research adds weight to the suspicion that financial agents erode the long-term wealth- and employment-generating capacities of national corporations. In addition, however, the results also reveal the dynamic restructuring processes triggered by these players which, at least in the specific case investigated, provided an acknowledged corrective and contributed to the cluster's recent resurgence.
\end{abstract}

Keywords: regional clusters, financial investors, firm finance, media industry

JEL classifications: G34, O18, R11, L82

Date submitted: 21 November 2008 Date accepted: 15 May 2009

\section{Introduction}

Criticising the greed and immorality of financial investors may appear not particularly original these days. Even before the current economic crisis and the associated loss of confidence in the global financial system there had been growing concern over the rise of new financial agents such as foreign private equity and hedge funds and the increasing power that these players hold over a significant part of a nation's assets due to the acquisition of a range of firms in important industries such as media (e.g. NZZ, 2006). The case of ProSiebenSat.1 Media AG, one of the two dominant private broadcasting groups in Germany and of utmost importance within Munich's media

\footnotetext{
*Department of Geography, Ludwig-Maximilians-University, Luisenstr. 37, D-80333 Munich, Germany. email<zademach@lmu.de>
} 
cluster, provides an excellent example of this trend. After the insolvency of the former mother company of ProSiebenSat.1, the Kirch Group, in 2002, the corporation was acquired by US media mogul Haim Saban who became the first major foreign investor to enter the German media market. In 2006, Saban resold ProSiebenSat.1 after substantial restructuring at a profit of more than $€ 2$ billion, and now a fund controlled by two private equity firms, KKR and Permira, holds a majority stake in the corporation. The latest developments have seen massive cost-cutting measures and an apparent deterioration in programme quality leading to diminishing audience shares, which, in turn, have resulted in reduced advertising revenues causing the stock price to decline to historical lows. This tight situation notwithstanding, the executive and supervisory boards of the group still proposed a marked increase in dividends in 2007 and distributed a payout to the shareholders that equals three times the net profits.

At first glance, the case of ProSiebenSat.1 appears to provide a clear illustration of the consequences of what is seen by some as a specific paradigm in the global capitalist system, also referred to as 'financialisation' (Froud et al., 2000; Williams, 2000; O’Neill, 2001; Epstein, 2005; Krippner, 2005; Leyshon and Thrift, 2007; Dore, 2008). As general trend to be found in most Western national economies (Engelen et al., 2008a), financialisation is usually seen to imply increasing pressures for higher returns on the capital employed. Recent work in economic geography has yielded valuable insights into this development and the possible implications of finance-driven capitalism for single industries and individual companies, including the undercutting of corporate interests and alleged asset stripping as part of attempts to drive profitability, as well as the damage to employment and, in turn, regional welfare (Christopherson, 2002; Gibbon, 2002; Zeller, 2003; Pike, 2005). In particular, this work illustrates that the growing power of capital markets and new financialised players, short-term profit orientation and the paradigm of shareholder value tend to disembed regional social relations and to have devastating effects for regional labour and supply markets.

However, the relationship between an economy's integration into global financial circuits and its development performance is, at best, not yet proven, and-depending on case and context-more ambiguous than might be expected. Specifically, there is a need for empirical research into the effects of economic financialisation beyond nation-state centred analytics, such as into the interaction between global financial expansion and the development of regional production or innovation systems (e.g. Schamp, 2003; Thierstein, 2003; Zeller, 2003). The shortage of research into the impacts of financialisation at a sub-national level relates to the fact that a significant part of the literature regards financialisation as an isomorphic and generalised trend, in which even national institutional particularities do not play a major role (Engelen, 2003, 2007; Engelen et al., 2008b; Clark and Wójcik, 2007). This in part is due to the origins of financialisation studies in the discussion on globalisation, where it has aimed to redress the state-versus-markets framework (Dixon and Monk, 2008; Monk, 2009). With respect to the work on regional clusters, on the other hand, Pollard $(2007,380)$ observes that commodity production in firms and production networks receives much greater analytical attention than the flows of money and capital which finance those firms and networks, and hence criticises that 'the financial elements of the "industry in the air" of industrial districts have, with few exceptions, been largely ignored'.

Against this background, this article attempts to shed further light on the relationship between economic financialisation and regional development in the specific context of 
Table 1. Number of establishments and sales in Munich's film and TV industry

\begin{tabular}{lrrr}
\hline & 2004 & 2005 & 2006 \\
\hline Establishments & & & 1069 \\
$\quad$ Film production/post production & 982 & 1027 & 72 \\
Film rental and distribution & 74 & 76 & 34 \\
Broadcasting & 51 & 40 & 85 \\
TV production (in TV studios) & 61 & 72 & 1302.7 \\
Sales (million $€$ ) & & & 956.8 \\
Film production/post production & 1718.7 & 1525.5 & 2399.1 \\
Film rental and distribution & 703.8 & 754.1 & 467.7 \\
Broadcasting & 3440.5 & 3621.0 & 434.7 \\
TV production (in TV studios) & 384.7 & & \\
\hline
\end{tabular}

Source: Bayerisches Landesamt für Statistik und Datenverarbeitung, 2008.

a regional industry cluster. ${ }^{1}$ The objective in doing so is not to take a strong moral position on the question of the net distributional and efficiency outcomes of the financialisation model, but rather to emphasise that the induced and cumulative effects triggered by the expanding role of financial investors, and their practices must also be taken into account when it comes to appraising its consequences for regional development. This research draws on the well-established case of Munich's film and TV industry, which experienced a period of severe depression from 2001 onwards related to the afore-mentioned bankruptcy of the Kirch Group (Gräf, 2005; Bathelt and Gräf, 2008). More recently, however, the cluster appears to have recovered and displays respectable growth in certain parts of the industry (Table 1): Whilst in the broadcasting market the process of consolidation continues and corporate restructuring is still on the daily agenda (as witnessed by the decreasing number of broadcasters), the film production/post production and TV production segments have seen a moderate net growth in the number of companies from 2004 onwards, along with substantial growths in sales in TV production and film rental and distribution. Furthermore, two recent surveys (Ernst \& Young, 2006; IHK, 2007) as well as the results of interviews carried out for this project with company representatives all predict solid future prospects for the local film and TV industries.

The study in hand takes this development path as a point of departure and addresses the setting of Munich's film and TV industry before and after the bankruptcy of the Kirch Group. In this way, it seeks to demonstrate the extent to which the structural changes within the cluster are associated with both immediate and cumulative results of the entry of new financial players and their modes of operation. The results of the research support, at least initially, the argument that financialised practices result in harmful outcomes at the local level. However, they also reveal that the apparent damage caused by the forces of global finance may create the conditions for a necessary restructuring and longer-term creative, technological and institutional revival within the

1 Clusters are regarded here - in a very general manner - as spatial concentrations of firms which cooperate in order to solve collective action dilemmas [for a critical review of the cluster concept, see e.g. Martin and Sunley (2006)]. 
fabric of an industry cluster. The investigation thus indicates the extent to which adjustment processes related to the entry of financial investors do not merely imply destructive effects for a local industry cluster, but, as in this particular case, can foster new marketing strategies and creative ideas - consequences from which both Munich's film and TV industry and the region as a whole could in a mid-term perspective derive substantial benefits.

The remainder of this article is structured as follows. The next section consolidates general perspectives on financialisation as a trend fostering economic restructuring worldwide and links these perspectives with recent conceptual advances on the development of regional industry clusters. Section 3 then sketches the context of this research and describes the methods applied in undertaking the empirical research. Sections 4 and 5 present the results of the study by contrasting the situation in Munich's film and TV industries before and after the bankruptcy of the Kirch Group. Section 6 concludes.

\section{Global finance and regional production systems: literature review and theoretical perspectives}

A prominent argument in the literature on regional clusters focuses on the advantageous interplay of geographically proximate and distant social and economic relations for learning and innovation (e.g. Maskell and Malmberg, 1999; Krätke, 2002; Bathelt et al., 2004; Boschma, 2005; Malmberg and Maskell, 2006). Following this line of reasoning, research on a variety of media clusters around the globe has untangled the significance of trans-local pipelines and the multiscalar architecture of clusters within this industry (e.g. Scott, 2002; Bassett et al., 2003; Mossig, 2008; compare also Faulconbridge, 2007). As a result, successful clusters are today considered to fruitfully combine external and internal sources of knowledge in complementary local and global networks (Table 2). Likewise, a prosperous cluster should show a certain degree of both coherence and diversity at the same time:

In order to exist over time, a cluster has to develop and maintain a structure which enables diversity within its area of competence, as well as a minimum of coherence in its focus. This includes the development of a common identity surrounding a particular value chain and the need for firms to share similar views and make similar decisions with respect to technological choices. (Bathelt, 2005, 204)

An additional factor which has become well established being supportive for cluster development is the ability to access funding. In this regard, e.g. Mossig (2004a) or Glassmann (2008) have demonstrated that the availability of capital acts as a bottleneck for entrepreneurship and represents an essential prerequisite for the emergence of localised, flexible and specialised production networks. Similarly, Coe's (2000) research on the film and TV industry in Vancouver as well as the study by Bathelt and Gräf (2008) - the latter two addressed the case of Munich, too, conducting empirical research between 2002 and 2004- have shown that cluster growth depends to a significant extent on linkages with external markets including the co-financing of film productions by foreign partners, whilst a lack of additional sources of finance may limit the growth prospects of a cluster. 


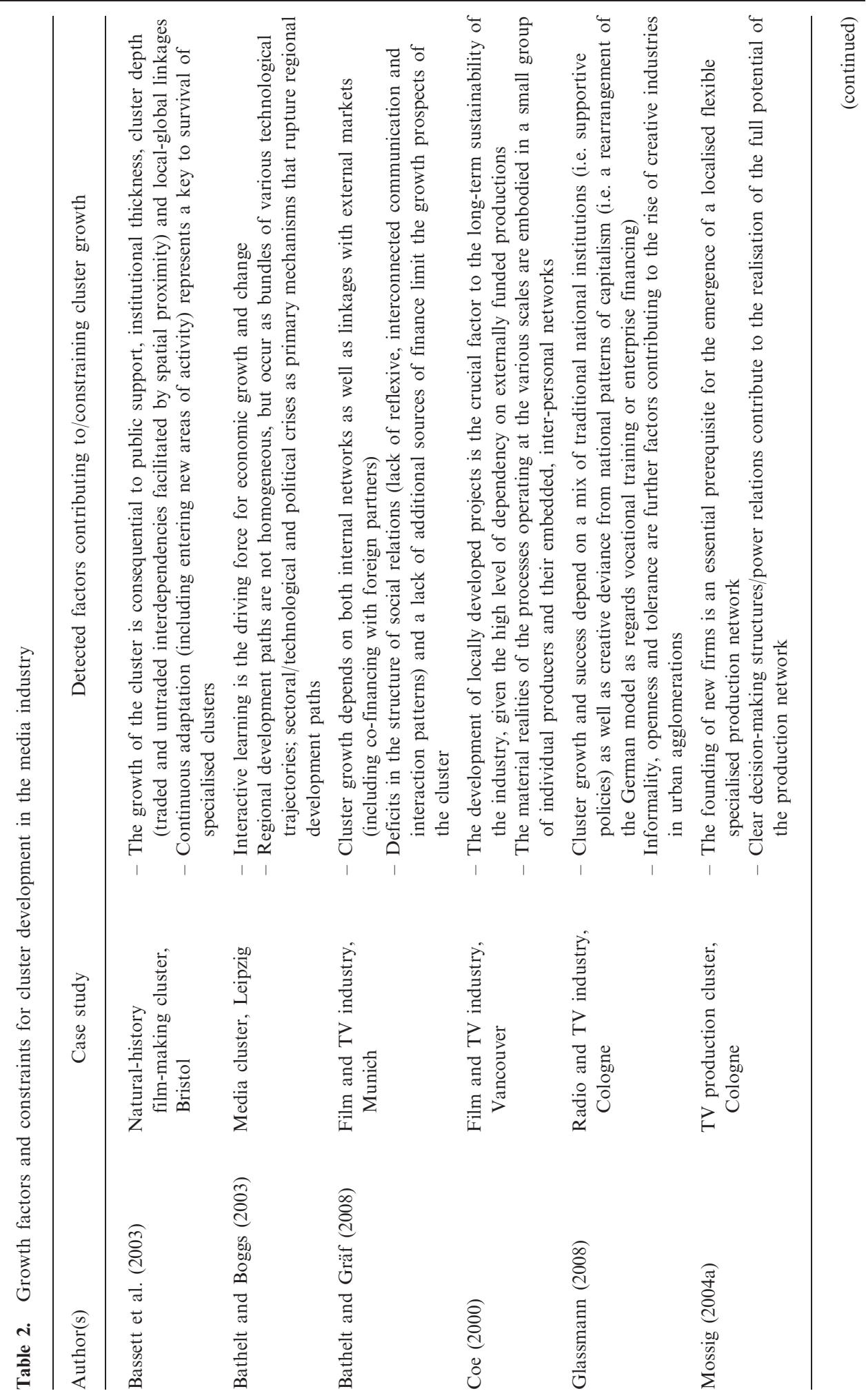




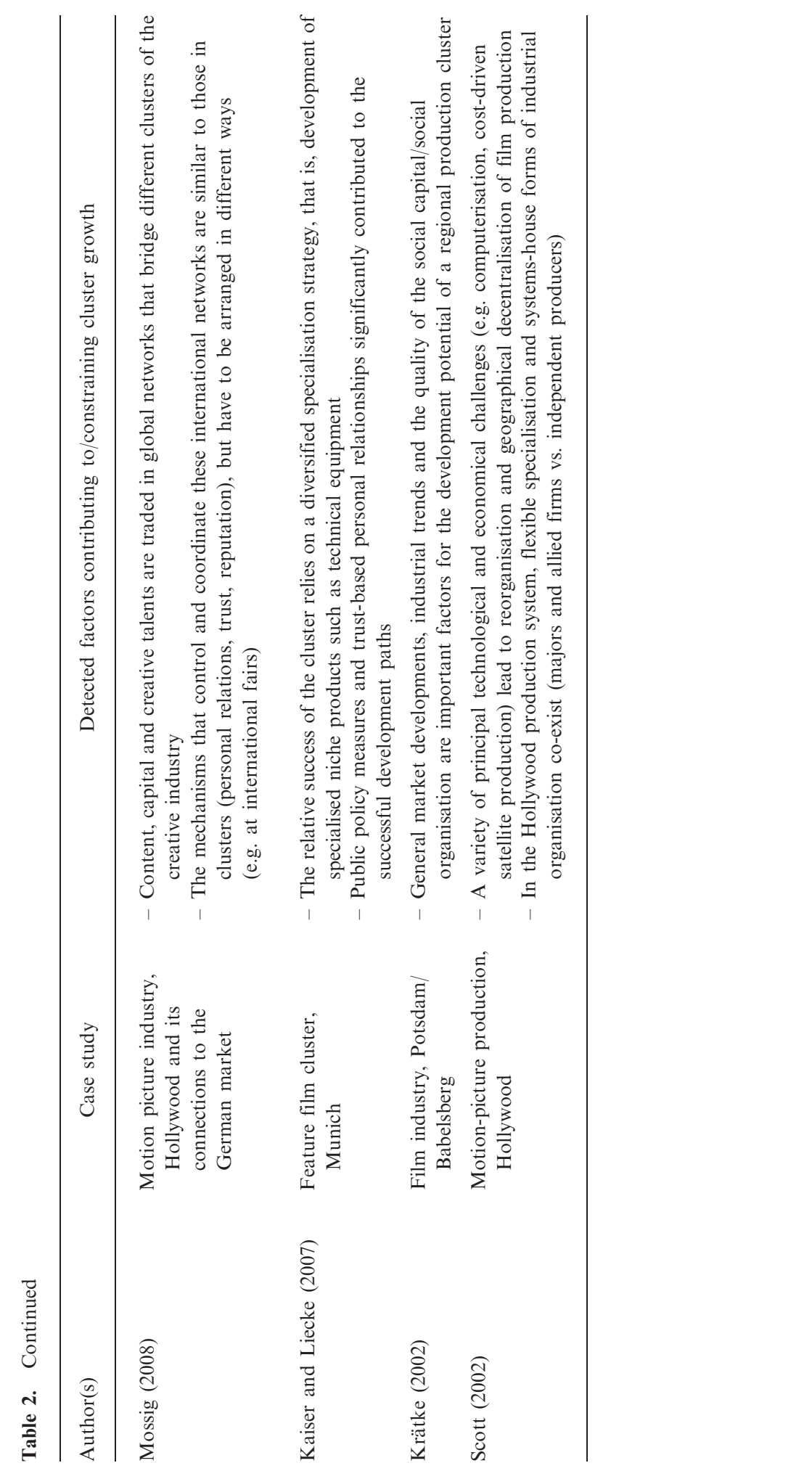


Within traditional thinking, a functioning financial system enables the efficient allocation of capital to its most productive use, thus contributing to maximise overall wealth. This picture, however, is called into doubt by the financialisation literature in which it is argued that the world of finance represents an independent, self-referential world with own dynamics, values and habits, and in which the salutary function becomes increasingly questioned. Broadly speaking, financialisation ${ }^{2}$ signifies a process in which financial markets, agents and objectives take on an ever-increasing role in the sum of economic, cultural and political activities within and beyond a national economy (Epstein, 2005). This includes the growing power of financial institutions such as private equity firms, pension funds or venture capitalists, together with the enlargement of cross-border financial trading with a myriad of new financial products and instruments (Engelen, 2003; Clark and Wójcik, 2007), as well as the dominance of 'shareholder value' and 'equity culture' as modes of corporate governance (Froud et al., 2000; Williams, 2000; Gibbon, 2002; Pike, 2005; Dore, 2008).

Because the large majority of the new financial intermediaries are of Anglo-Saxon origin (see e.g. the ranking created by industry magazine Private Equity International, called the PEI 50), financialised investment practices are frequently regarded to lead to a greater influence of, or convergence towards, an Anglo-American way of capitalism. Yet even though the relevance of institutional differences may have been diminishing as a result of the rise of financial markets and the appearance of new border-crossing financial agents, it remains a variety of capitalisms with distinctive material and immaterial characteristics that moderates financial values and habits (Hall and Soskice, 2001). National institutional particularities therefore remain crucial, such as the logic of trust, commitment and loyalty in the coordinated market economy of Germany, as opposed to the less committed, liberal Anglo-American system (Christopherson, 2002; Engelen, 2003; Clark and Wójcik, 2005; Wójcik, 2006; Engelen and Grote, this issue).

But financialisation is not only a force that transforms corporate governance at the national scale; it also affects regional economies, their production structure and their spheres of actors, that is, owners, employees, banks and suppliers. Against this background, the influence of finance on the coherence, diversity and development of regional clusters becomes more ambiguous than in the traditional understanding of the financial system. The entrance of new financial players into regional production clusters impacts on these complexes by reshaping their coherence and diversity in differing ways (Table 3). On one hand, the entry of new financial agents may pose distinct problems to regional economies by disrupting the particular value chain and the local collectively competitive context. The control of focal companies by new financial intermediaries implies a potential tension between principles and agency incentives,

2 The term is used in different ways, with no consensus on a definition (e.g. Milberg, 2008; Engelen and Konings, Forthcoming): For a first group of scholars, financialisation refers to a pattern of accumulation in which profit making occurs increasingly through financial channels rather than through trade and commodity production or; in other words, the shift in corporate activities from the production and distribution of goods and services to the trading of financial assets; for others, in a more narrow use of the term, financialisation implies the dominance of 'shareholder value' as a mode of corporate governance, or a growing dominance of capital market financial systems over bank-based financial systems; in yet another interpretation financialisation corresponds to the increasing power of a financial institution, including the enlargement of cross-border financial trading, with a myriad of new financial products and instruments - a trend which is reflected, for instance, in the growing importance of pension funds. 
Table 3. Financialised capital and regional development

Financialised actors/practices

Regional development consequences

(De-localised) loan finance

Venture finance

Capital market/equity finance
Trust-based relations are replaced by market-based relations Break-up of regional networks

New marketing strategies of local banks due to greater competition

Firm foundation and increase of innovative firms

Development of new technologies/market niches

Intermediation between start-ups and established firms

Forced engagement in capital markets

Supply of capital/equity may preserve suffering companies

Restructuring, implementation of new management techniques, efficiency orientation etc. (hands-on investments)

Revaluation and recombination of (local) assets

Changing power relations (including loss of independence)

Access to global networks

through which localised value-creation and learning processes become subordinate to demands for short-term profitability (Asheim and Herstad, 2003). In this context, the tremendous growth of the private equity industry has provoked concerns among a variety of economic and political commentators. ${ }^{3}$ Most notably, these investors are accused of destroying long-term value in their portfolio companies, with consequences for local and regional development such as the disembedding of the regional social relations of ownership and control, caused by the concentration of shareholdings among institutional investors.

Furthermore, financialised actors and practices may also disturb the common identity and coherence of a cluster when trust-based relations are replaced by marketbased relations. After the entrance of new players, for example, online banks and formerly non-financial companies such as Virgin, General Electric or Porsche, which began to target particular segments of the financial markets, traditional banks were forced to reconfigure their market approach and centralise their organisational structure. After a decade of branch closing and the development of business fields such as investment banking, SMEs, in particular, face more and more difficulties in obtaining bank loans (Leyshon and Thrift, 1997; Tickell, 2000; Pollard, 2003;

3 Between 1985 and 2005, private equity funds experienced an average annual growth rate of $18.5 \%$. In 2007, a record of more than US\$ 680 billion of private equity was invested globally, up over a third on the previous year and more than twice the total invested in 2005 (Private Equity Online, 2008). The private equity industry consists, on one hand, of a rather small number of large funds which are in part publicly listed, and on the other hand of a large number of smaller, unlisted companies (Froud and Williams, 2007). Private equity firms acquire a controlling or substantial minority interest in a company and then attempt to maximize the value of that investment through different arrangements. In general, they receive a return on their investments through public offerings or the re-selling of their stakes to other (investment) companies. 
Klagge, 2004). Since regional banking systems play an important role in overcoming information asymmetries (e.g. Alessandrini and Zazzaro, 1999), this development implies potentially harmful consequences for regional development.

On the other hand, the agendas of the different groups of financial investors, including investment banks and private equity firms, have the net effect of encouraging an economy of permanent restructuring (Folkmann et al., 2007). Hence, the emergence of new agents and practices as well as the establishment of new trans-local linkages serve as powerful means of preventing or breaking out of declining to 'locked-in' modes of production. Firm ownership patterns and levels of capital stock are seen as central in enabling companies to change the scope and scale of their relationships. A change of ownership implies significant effects on the firms involved and their environments. As Chapman $(2003,315)$ notes '[c]hanges in ownership modify the internal structure and re-define the external relationships of the acquiring firm', and they 'allow the acquiring company to escape from many of the constraints which limited the freedom of the seller' (ibid, 323). Thus, foreign ownership can complement local cooperation or learning processes and permit investments which, through their interplay with the regional institutional context and industrial structure, emerge as value creating, that is, supporting or correcting the basic logic of value creation or knowledge exploration and exploitation.

Further positive impacts may arise from venture capitalists and the fast-growing amount of risk capital being used to support the formation of new companies (e.g. Martin et al., 2002). Venture capitalists support start-ups and new businesses in their early stages, providing not only capital, but also advice and contacts, and have a major influence on management decisions (Hellmann and Puri, 2000). With regard to the dynamics of the interplay between the availability of venture finance and new firm formation, Saxenian (1994) has shown that, contrary to popular belief, the venture capital industry in Silicon Valley emerged out of the region's base of technology enterprises, and not vice versa. As successful entrepreneurs reinvested their capital in promising local start-ups, they created a new and different kind of financial institution (compare also Cooke, 2002; Powell et al., 2002; Zook, 2002). In this sense, venture capital can be regarded as a distinct form of local finance, operating within global conventions.

In sum, financialisation is to be seen as a two-edged sword: it can result in positive impacts such as improved economies of time, allocative efficiency, intensified competition and greater openness - up to a threshold. Beyond this point, it derails the economic development of a regional cluster by destroying shared resources and long-term learning constellations. To appraise the behaviour of financial institutions thus becomes an issue of the context in which their influence unfolds. The question that arises is whether financialised capitalism can contribute to changes in a region's structural setting or institutional arrangement, including its coherence, diversity or internal and external relations. Concerning this matter, it has to be taken into account that clusters are embedded hybrids, wherein parts of the system adapt to new situations and other parts persist. Change in these systems can occur when paths collide - not necessarily violently - such as with the translation of foreign production methods into regional production systems (Gertler, 2004). Following this multi-trajectory perspective, the subsequent sections of this article exemplify the complexity of the consequences of financialised investment practices taking the media industry in Munich as an illustrative case. 


\section{Specification of analysis}

The growth of Munich's film and TV cluster in the post-war period has been influenced by a number of factors such as the historical roots of the industry ${ }^{4}$ and differing means of public support. ${ }^{5}$ Of particular relevance has been the liberalisation of the market in 1984; since then the structure of the German TV market is shaped by the co-existence of public and private broadcasters (e.g. Mossig, 2004b). The public broadcasters include nine regional channels and two channels broadcasting nationwide (ARD and ZDF). They are financed from fees paid by TV and radio owners. In 2007, public broadcasters accounted for close to $45 \%$ of the viewing public. In contrast, private broadcasters generate most of their revenue from advertising, and the private market is dominated by a group of channels that belong to two distinct corporate groups: the RTL Group in Cologne, owned by the fully integrated internationally operating media conglomerate Bertelsmann $\mathrm{AG}$, as well as the Munich-based ProSiebenSat.1 Media AG.

Munich's film and TV industry, that is, broadcasting, film/TV production, distribution and services, employs $\sim 16,000$ people overall (Ernst \& Young, 2006; IHK, 2007). In spatial terms, the industry is highly concentrated in Unterföhring/Ismaning, about $10 \mathrm{~km}$ north-east of the city centre, and in Grünwald-Geiselgasteig which is about the same distance to the south of the centre (Figure 1). The city centre, on the other hand, hosts a large number of specialised training and funding organisations such as the MediaCampus Bavaria or the Bavarian Film and TV Fund, which provide a unique institutional infrastructure. The regional public broadcaster, Bayerischer Rundfunk, and a number of productions and distribution firms - Constantin Film and Tandem Communications, for instance - are also located in the centre.

4 As in other industrialized countries, the German media industry is highly concentrated in urban centers, namely Berlin/Babelsberg, Cologne, Hamburg and Munich. This spatial concentration relates primarily to the historical development of the industry. Until the 1940s, Germany had one of the strongest and most productive feature film industries in the world. The industry seized that position not least because of its collaboration with the Third Reich regime and consequently, after gaining control over Germany, the Allies prohibited filmmaking in the immediate aftermath of the war. The subsequent restructuring followed different processes in each of the four occupation zones. The Soviets sponsored the reconstitution of a film making monopoly in their zone of occupation and established German Film AG (DEFA) in Babelsberg. The British military government focused mainly on the broadcasting industry and supported the establishment of relatively small production infrastructures, which later developed into leading public broadcasting corporations in Hamburg and Cologne. In contrast, the US authorities initially showed reluctance to license any German filmmakers in their zone of occupation, but used their position as victors to open up Europe to Hollywood movie products (e.g. Shandley, 1999; Kaiser and Licke, 2007).

5 Support for the industry is offered from different levels of government, that is, from the state, federal and European levels. This support can be characterized either as specific sectoral infrastructural measures (e.g. provision of office space or studio halls as in the case of the establishment of the Bavarian Film Center in Geiselgasteig, or public support of specific events or organisations) or the direct financial promotion of film productions. Concerning the latter, the German government implemented a film promotion agency (Filmförderungsanstalt, FFA) in 1968, and in the late-1970s and early-1980s the state governments followed up with public film funding. By ensuring that a certain multiple of the support (in Bavaria, for instance, this quota amounts to $150 \%$ ) was spent locally, these funds provided support to almost all aspects of film production, including for instance script writing, distribution, professional training and cinematographic festivals. The combined film funding provided by the national and state government exceeds $€ 200$ million per annum (Kurp, 2004). European funding adds to this, playing however a rather minor role (in 2005, for instance, the German market received a share of less than $€ 10$ million from the European media plus program). 


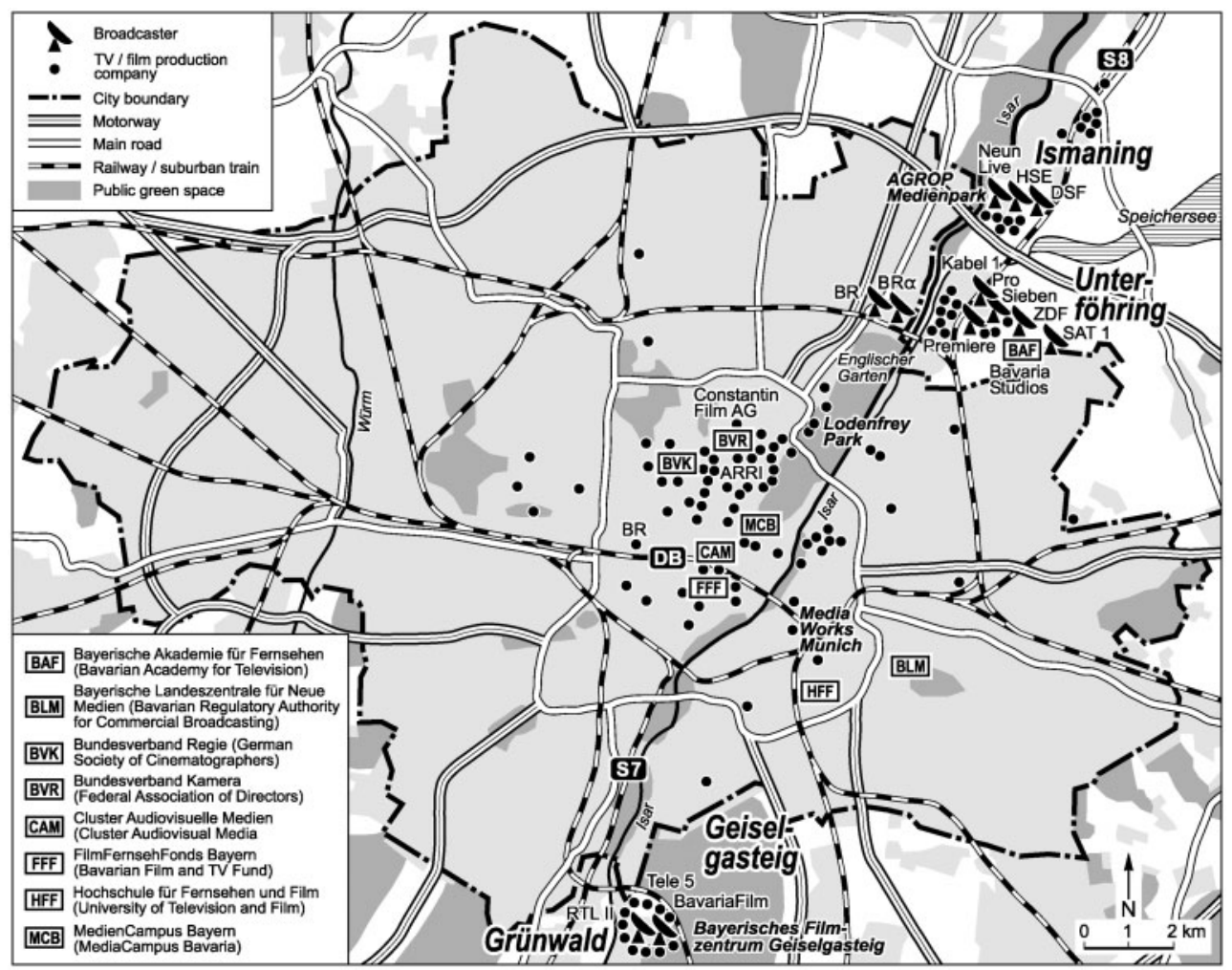

Figure 1. Location of broadcasters, important production companies and institutions related to film and TV in Munich, 2008.

According to the results of the research on the internal and external dynamics of Munich's film and TV cluster by Bathelt and Gräf (2008, 1955-1957), this fragmented territorial distribution limits the opportunities for informal communication and information flows also referred to as 'local buzz'. There is, however, an exceptionally high degree of functional and organisational interconnectivity within Munich's film and TV industry: Bayerischer Rundfunk, for example, is not only present in the city, but has broadcasting and production sites in Unterföhrung, too. Another example is Bavaria Studios, one of the largest service providers of film and television production facilities in Europe, which maintains studios in both Unterföhring (eight studios), where it also holds its principal office, and Geiselgasteig (10 studios). As regards the ownership structure, Bavaria Studios is owned by Bayerische Landesbank, ZDF, and Bavaria Film in Geiselgasteig, who each hold 33.3\% of the company, while Bavaria Studios in turn is itself owner of SetLogistics, a film service company in Geiselgasteig.

The two following sections of this article shed further light on these preliminary observations and address the organisational relationships in the landscape of Munich's film and TV industry by comparing the situations before and after the bankruptcy of the Kirch Group. Methodologically, the research was approached as a case study, combining literature review and the compilation of company and cluster information from various sources, together with qualitative interviews. In detail, the work involved three analytical steps. In the first step, different sources of information were used to 
identify all of the players in Munich's audiovisual industry. In the second step, a detailed scheme was drawn up for each of the identified companies to illustrate their ownership structures and the way these had changed over time, using information available through inspection of the commercial registers. Finally, in the third step, the role of changing ownership and finance was explored through 38 semi-structured interviews with film production and service companies, broadcasters, private and public financiers, and other supporting institutions in summer 2007 and spring $2008 .^{6}$ With regard to the impact of changing equity and ownership structures, the schematic recording of shareholdings proved helpful in ensuring that none of those interviewed needed to worry about divulging anything that was not already in the public domain. This procedure corresponds to Gräf's $(2005,22)$ observation that studying finance in the media industry has to be seen as an especially challenging task in terms of data availability and sensitivity.

\section{Setting of Munich's film and TV industry before the Kirch crisis}

The development of the film and TV industry in Munich during the post-war period was closely connected to the formation of two distinct, rather closed corporate networks. These two networks are highlighted in Figure 2 which displays the ownership structures of the most significant part of Munich's film and TV industry just before the collapse of the Kirch empire. While there were initially interconnections between these two networks, over the ensuing decades they became less intertwined.

The first integrated network was that of the previously mentioned regional public broadcaster Bayerischer Rundfunk, including its shareholding of the Bavaria Film Group. ${ }^{7}$ Bayerischer Rundfunk was established in Munich in 1950 as one of nine regional TV stations in the federal structure of the ARD, the cooperative association of public broadcasters in Germany. As licensing fees are allocated according to the population of the Länder-Bavaria is Germany's second most populous province (after North Rhine-Westphalia or NRW) - and regional broadcasters are, in return, obliged to respectively contribute to the common program of ARD, Munich as well as Cologne in NRW were able to establish a strong infrastructure for TV production at an early stage (Mossig, 2004b).

The establishment of ZDF's regional studio in the 1960s gave further impetus to the growth of the media industry in Munich. Since they received a lower degree of public funding, ZDF was forced to adopt a less integrated strategy than Bayerischer Rundfunk and worked mainly in partnership with independent producers. This laid the foundation for the rise of Leo Kirch's media empire, eventually becoming the second rigid network in Munich's media landscape. Kirch launched his business in

6 The interviews were conducted with either one or two corporate executives in conference rooms in the companies' locations and usually lasted between 75 and $90 \mathrm{~min}$. All interviews were digitally recorded, transcribed and condensed into a matrix scheme for analysis.

7 The Bavaria Film Group, based on the tradition of a studio company founded in 1919 in Geiselgasteig, has steadily grown to become a group of more than 30 subsidiaries and shareholdings, among them the well-known Bavaria Studios in Filmstadt Geiselgasteig in the South of Munich. Bayerischer Rundfunk has held shares in the Bavaria Film Group since the 1990s. Two other regional public broadcasters (SWR and WDR) took up interests in the Group back in the $1950 \mathrm{~s}$ - a period when the cinema industry dominated the German entertainment market and followed the agreement 'No meter film for the TV market'. 


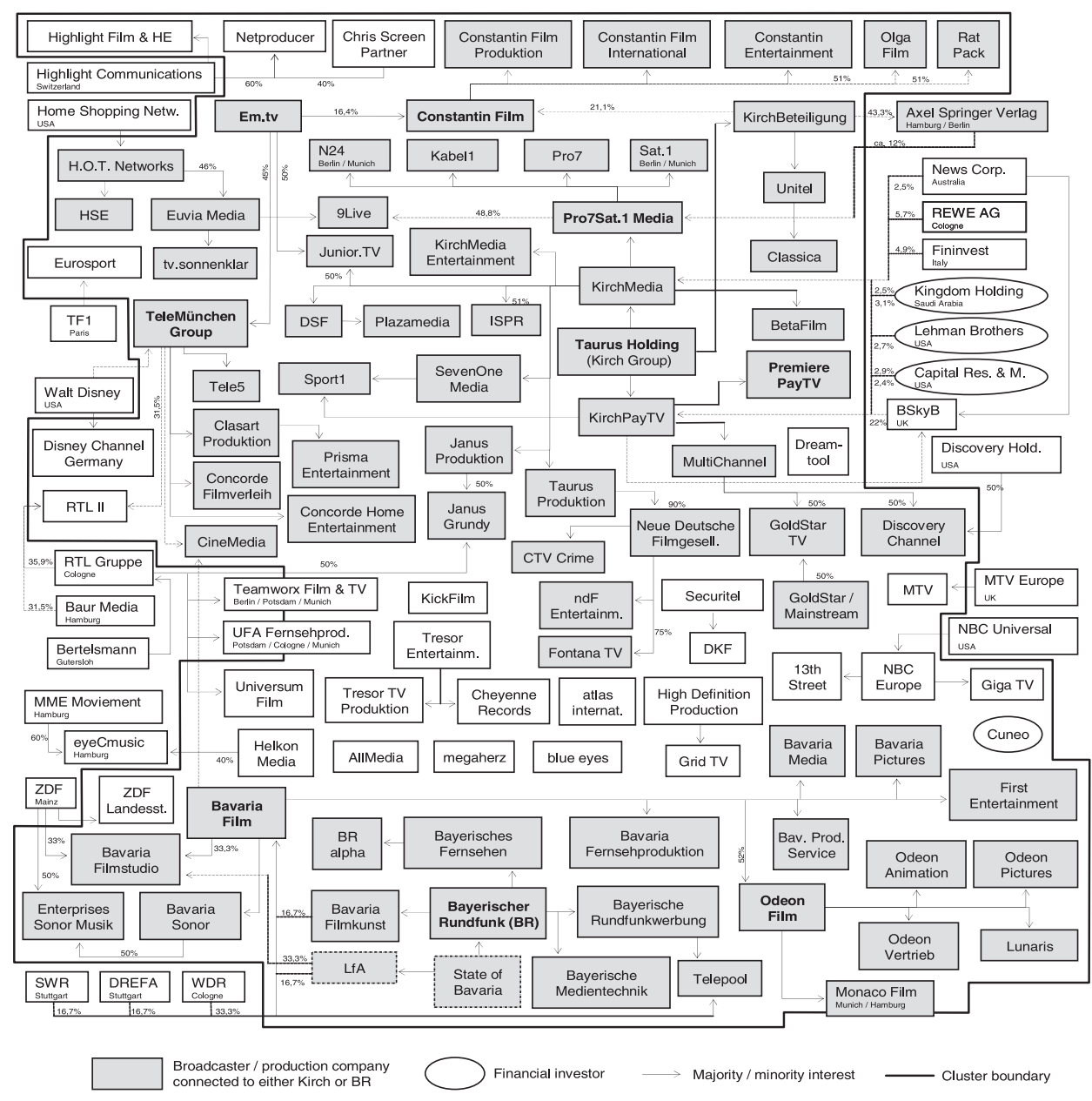

Figure 2. Corporate ownership in Munich's film and TV industry, 2002.

the 1950s with the establishment of two distribution companies Beta Film and Taurus Film. Initially, their main customers were ARD and, above all, ZDF. As a consequence, the two public broadcasters neglected to build up their own comprehensive film libraries, and Kirch was then able to substantially increase prices. Furthermore, with the liberalisation of the national TV market in the 1980s and the entry of new players, the market for his products broadened. In order to secure his trade channels, Kirch quickly took out shares in the new market participants and integrated further levels of the value chain into his corporate group, systematically following the vision of a fully integrated media complex (Kiefer, 2003). He was one of the three founders of the Sat.1 channel in Berlin, and via his son Thomas Kirch established ProSieben in Munich, followed in the 1990s by Kabell (initially Der Kabelkanal, from 2005 onwards kabel eins), and the sports channel DSF. Kirch also forced his way into the pay-TV sector by means of a shareholding in Premiere as sole supplier in this segment of the market, the remaining interests being held by Bertelsmann and the French Canal Plus. 
In 1996, Kirch established DF1 as the first digital pay-TV channel in Germany (Woldt, 2002). In 1998, when European and German cartel commissions prevented Kirch and Bertelsmann from implementing a common pay-TV platform, Bertelsmann sold his shares in Premiere to Kirch, who then merged DF1 and Premiere into Premiere World.

At the height of its growth, the Kirch Group was valued at $€ 5.6$ billion and employed close to 9500 staff, compared to a workforce of $\sim 3100$ at Bayerischer Rundfunk (including radio broadcasting). Thanks to this position as an important employer and close personal ties of Kirch to highest level politicians, the group was also strongly interwoven with government (e.g. BBC, 2002). Apart from the private channels mentioned previously, its $\sim 150$ units included a number of TV production companies, the biggest film library in Europe, rights to two World Cup soccer competitions and a significant share of the Formula One car-racing license (Formatt, 2005; IHT, 2007).

In this environment of rigid networks, the broadcasters held the most powerful position in the value chain. The majority of TV productions were financed either solely by broadcasters or via combined financing from broadcasters and public film funds or the financial resources of production companies. ${ }^{8}$ That is, the public broadcasters or private channels supplied the budget and in return obtained all rights to the production. Until 2002, dependent production companies, that is, companies with $25 \%$ or more of their shares held by another organisation, accounted for close to $50 \%$ of the overall production volume (Formatt, 2005, 30). For the typically small and medium-sized production companies, bank loans following the specific German Hausbank principle ('relationship lending', cf. Schamp, 2003; Klagge and Martin, 2005) served as the primary source for additional funding and bridging finance requirements (Clevé, 1997; Glassmann, 2008). International co-productions and internationally co-financed projects have in comparison been very rare.

To a large extent, this characteristic also holds true for the local motion-picture industry: notwithstanding substantially higher budgets and a more complex financial value chain - that is, higher risk taking, which is usually shared among a greater number of investors - network dynamics within the Munich feature film industry are particularly intense within a relatively small group of local organisations. The most notable of these organisations are Constantin Film and Bavaria Studios. It was only in the manufacture of technical equipment used in the production process that Munich-based firms held a leading position in the world market (ARRI for camera equipment is the classic example). As far as production, financing and distribution are concerned, the Munich feature film industry has been only marginally integrated into the global industry (Kaiser and Liecke, 2007).

Overall, by the end of the 1990s, Munich's film and TV industry was in a situation with a high degree of mutual interdependence at the local level and underdeveloped links to external markets. The low orientation towards external sources of knowledge prevented substantial growth impulses to the region. With the boom of the New Economy and the high level of local and domestic demand, there was also no real need to develop new ideas or marketing strategies. Against this background of vulnerability,

8 The supportive public funding instruments were, however, established only in the second half of the 1990s (FFF in 1996, Bankenfonds in 2000). 
it was not surprising that the economic downturn at the beginning of the new millennium along with a significant reduction in advertising expenditure brought tremendous challenges to the cluster.

\section{Regeneration of the cluster in the paradigm of global finance}

The massive expansion strategy of the Kirch Group imposed a high level of demand for capital. In particular, the foray into the pay-TV segment, in which Kirch attempted to establish pay-TV in Germany single-handedly following the rejection of the joint proposals with Bertelsmann, turned out to be extremely costly. In the spring of 2002, Kirch's empire finally collapsed with debts amounting to $€ 10$ billion - the largest company bankruptcy in German history thus far. The Bayerische Landesbank, half-owned by the state of Bavaria, was Kirch's biggest bank creditor, holding $€ 1.9$ billion in Kirch loans, the other main creditors being all the leading German commercial banks (Deutsche Bank, Dresdner Bank, Commerzbank, HVB, DZ Bank) as well as Lehmann Brothers and JP Morgan (BBC, 2002). Among the shareholders, all losing their investments, were also Mediaset owned by Silvio Berlusconi as well as Rupert Murdoch's News Corp, both of them displayed interests to buy certain units of the group, most notably ProSiebenSat.1.

Much of the German business and political establishment attempted to prevent the arrival of even more powerful foreign media barons and favoured a German solution; notwithstanding, after several months of negotiations involving a broad range of stakeholders including state and national governments, in the end, when the last rival suitor Heinrich Bauer Verlag, a German publisher which already owned part of RTL and whose bid would have put the deal under antitrust scrutiny, decided to pull out, it was the group of strategic investors around US media mogul Haim Saban that succeeded in acquiring ProSiebenSat.1. In the following, the section first describes the immediate effects of the arrival of this new agent and his financialised modes of operation with regard to the restructuring of ProSiebenSat.1 as well as the adjustment process that followed in the industry. It then places the restructuring of the industry into the broader regional context.

\subsection{Dissolution of the Kirch group and corporate restructuring under Saban and KKR/Permira}

Haim Saban's acquisition of ProSiebenSat.1 Media AG, including the four channels ProSieben, Kabel1, Sat.1 and N24 (the latter two by now still located in Berlin ${ }^{9}$ ) which together account for $\sim 40 \%$ of the nationwide $\mathrm{TV}$-advertising market, significantly altered the German TV landscape. For the first time, a foreign group of financial investors had gained control of an important German player. In coverage by the international press, the deal was called a transforming moment in German television that brought 'a shrewd, bare-knuckles Hollywood operator to a market dominated by the state and by family-owned companies like Bertelsmann' (NYT, 2003), that is,

9 In November 2008, ProSiebenSat.1 indeed announced that by June 2009, Sat.1, ProSieben and kabel eins shall all be located together in a new structure in Munich, thus combining all the German Group's general-interest stations in a single building at a single site. Sat.1 and all support functions will be relocated from Berlin. The plan affects a total of 350 employees. 
Table 4. Basic data on ProSiebenSat.1 Media AG/group, 2001-2007

\begin{tabular}{|c|c|c|c|c|c|c|c|}
\hline & 2001 & 2002 & 2003 & 2004 & 2005 & 2006 & $2007^{\mathrm{a}}$ \\
\hline Sales (million $€$ ) & 2015 & 1895 & 1807 & 1834 & 1990 & 2095 & 2703 \\
\hline Net income (million $€$ ) & 74 & 15 & 45 & 134 & 221 & 241 & 89 \\
\hline Employees & 3029 & 3072 & 2781 & 2899 & 2730 & 3097 & 5930 \\
\hline Dividend common stock (€) & 0.14 & - & - & 0.28 & 0.82 & 0.87 & 1.23 \\
\hline Dividend preferred stock $(€)$ & 0.16 & 0.02 & 0.02 & 0.30 & 0.84 & 0.89 & 1.25 \\
\hline Payout (million $€$ ) & 29 & 1.9 & 1.9 & 63.5 & 181.6 & 192.5 & 269.9 \\
\hline Payout ratio ${ }^{\mathrm{b}}(\%)$ & 39.2 & 13.0 & 4.9 & 47.5 & 82.2 & 80.0 & 303.3 \\
\hline Stock price $31.12 .^{\mathrm{c}}(€)$ & 5.75 & 6.50 & 13.25 & 13.50 & 16.35 & 24.85 & 16.39 \\
\hline
\end{tabular}

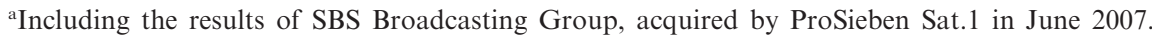

${ }^{\mathrm{b}}$ Compared to consolidated profit for the year.

'ISIN (International Securities Identification Number): DE0007771172.

Sources: Corporate annual reports, Onvista.

the injection of someone with a very different background and outlook into what had been a rather insular business.

Within the company, the change of ownership resulted in the replacement of management executives and further job losses. Pursuing a strategy of diversification, ProSiebenSat.1 under Saban aimed to broaden its focus by means of both organic growth (i.e. intensifying the expansions into merchandising and the new media segment), and also by the acquisition of a number of smaller new media companies such as the video community 'MyVideo' or the social network 'Lokalisten'. Together with cost-cutting measures that included an overall loss of more than 300 jobs between 2002 and 2005, the turnaround and growth strategy initiated by the new owner proved fairly successful, with considerable increases in sales, market share and net income (Table 4). As a result, Saban was able to make a profitable sale of his shares to an investment fund controlled by the private equity firms Permira and Kohlberg Kravis Roberts (KKR) in December 2006. Thereupon, ProSiebenSat.1 Media AG acquired SBS Broadcasting (from then onwards ProSiebenSat.1 Group), another portfolio company controlled by Permira and KKR, for a total consideration of $€ 3.3$ billion. Due to this acquisition being fully financed externally, the debts of ProSiebenSat. 1 increased to about $€ 3.6$ billion and, as a result of the burden of debt servicing, profits decreased by two thirds to $€ 89$ million. Nevertheless, the group increased dividends for both common and preferred stocks and distributed a $€ 270$ million payout to the shareholders.

One point that interviewees highlighted when describing the changing modes of corporate governance from Kirch to Saban-'from a surely family-orientated company to a transparent, shareholder-driven corporation, ${ }^{10}$ (Broadcaster BC4, July 2007) —was the implementation of English as the corporate language. Furthermore, ProSiebenSat.1 switched its accounting and reporting system and since 2003 has compiled its annual and quarterly reports in accordance with the international financial reporting 
standards IFRS, whereas previously they had conformed to the German commercial code HGB. Another point to make in this context is that the entry of new players and the reconfiguration of ownership structures involved an augmented transfer of external knowledge that complemented the local knowledge base. In a perspective of 5 years' distance, one interviewee who worked with Kirch until the bankruptcy and is now a deputy director with a rival broadcaster described these beneficial effects as follows:

I experienced it when Haim Saban took over at that time and came along with his team. As a person he was very likeable - I met him twice - but what a massive clean out he implemented in that store... and of course he brought in his people from all over, with the result that, suddenly, Munich was the 'place to be'. (Broadcaster BC5, July 2007)

Moving on, he then commented on the recent takeover of SBS by ProSiebenSat.1 Media AG:

This [i.e. re-emergence of the location] has reciprocal effects. If KKR and Permira now build an important pan-European media corporation here, this will be of utmost importance for Munich as a centre for the industry, much more important than the period of superiority of the regional public broadcasters, i.e. the time when public broadcasting was far more powerful and Bayerischer Rundfunk was leading the way here in Munich. (Broadcaster BC5, July 2007)

Other interviewees were however more critical of the increased presence of international 'consultants', that is, executives of the equity firms involved and their self-referential behaviour. For instance, it was repeatedly reported that the investors put massive pressures on their target companies by playing them off against each other-with statements like 'You tell us prices are going down, but just two hours ago when we visited your competitor [also hold by this investor] we were told that prices are stable'. Then again, the same interviewees accredited these consultants for disseminating the knowledge they gained from previous investments in other contexts. These divergent valuations provide a first indication of the ambiguous effects that financial investors and their globalising practices may have on agglomerated production complexes and their performance. It is this ambiguity to which is turned in more detail now.

\subsection{Situating the restructuring of ProSiebenSat.1 in the context of the industry}

The facts given on the case of ProSiebenSat.1, including its re-sale from one financial investor to the next, exemplify the dynamic restructuring and increasing overall impact of (foreign) financial players on the media landscape in Munich. Figure 3, in which ownership is sketched out for 2008, aims to display these developments. The illustration highlights the broadcasters and production companies, which have experienced major changes in shareholder structure since 2002. In addition, the entry of a number of further financial investors such as Providence Equity, 3i, Wellington, or the Canadian pension fund OTPP becomes apparent. Although the number of film and TV companies under foreign control still accounts for only a smaller percentage of the total in absolute terms (IHK, 2007, 21), when measured in terms of the local workforce employed by the acquired companies, the influence of these financial investors has definitely reached a significant level. 


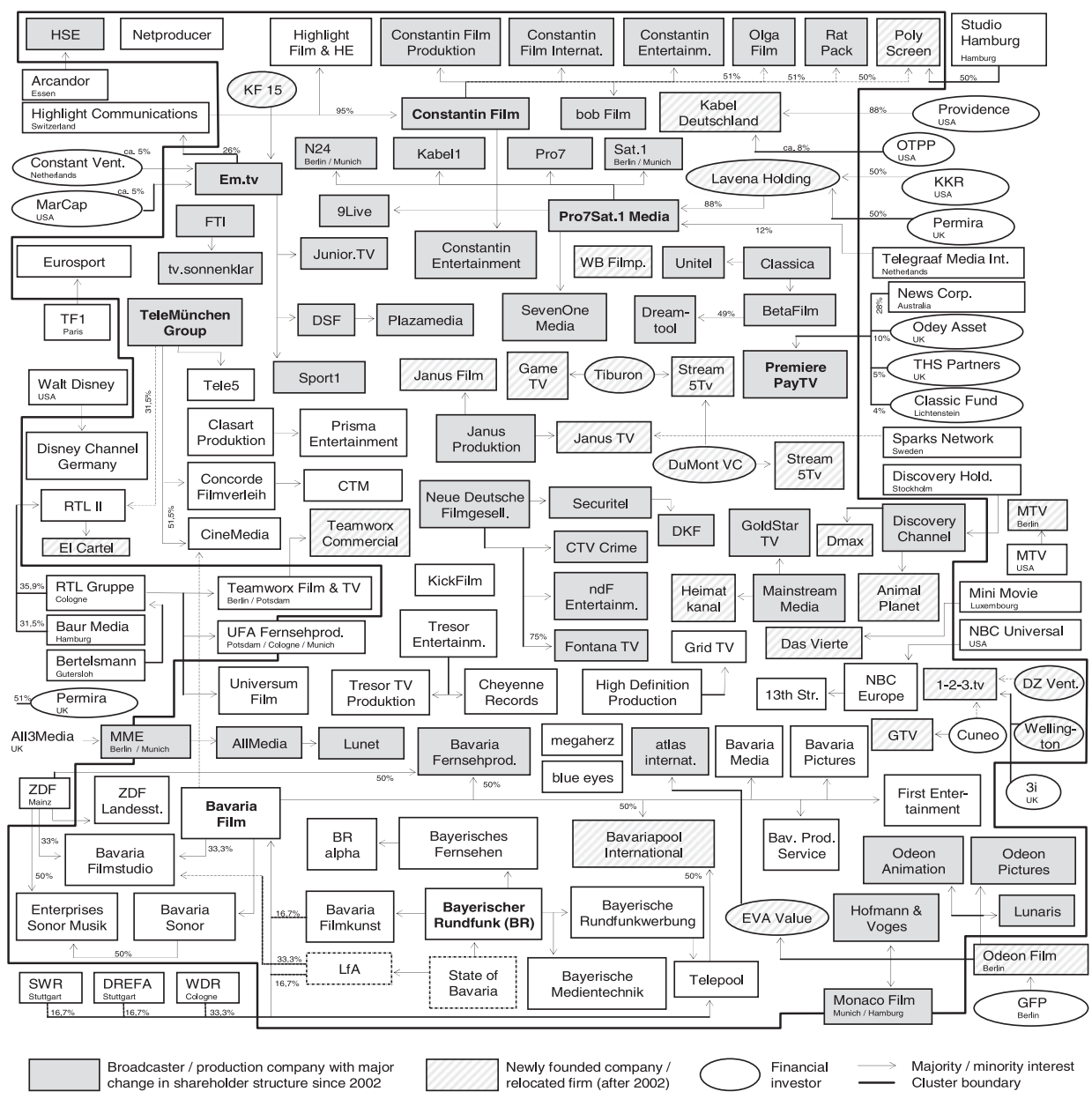

Figure 3. Corporate ownership in Munich's film and TV industry, 2008.

The following statement from one of the film producers interviewed illustrates the uncertainties under which the Munich film and TV industry has had to operate since these changes have occurred:

At the private channels, and of course most of all at ProSiebenSat.1, the bankruptcy of Kirch has caused considerable disruption. So did the consolidation by Saban which, for sure, was reasonable, but from the beginning everyone knew that this would not be a strategic partnership for 25 years, but a financial investment. From the first day with Saban it was clear that we were all operating within a timetable of only three or four years. (Film producer FP7, August 2007)

In this competitive environment of restructuring and high volatility, a range of adjustments took place. First of all, the majority of the commercial banks dismissed the media sector and became very restrictive towards clients in this segment. The implementation of the Basel II accord forcing banks to impose more strict requirements 
and demand greater security for loans reinforced this development and, as a result, only two banks continued to invest in the media market, namely the nationwide operating DZ Bank and local Reuschel Bank. The years 2003 and 2004 were the most difficult for film and TV producers and also for the service companies. At the national level, 2003 saw a net gain of 70 new independent producers, while in 2004, almost the same number of companies vanished and the overall number fell back to the level of 2002. ${ }^{11}$

A number of former Kirch production units and service firms bought out by their management were however able to survive and coped fairly successfully with the situation, for example, Neue Deutsche Filmgesellschaft (NDF), Plazamedia and Janus TV. While overall, Munich became a preferred location for higher-budget and rather capital-intensive productions, these companies were forced to adopt heavy cost-cutting measures, which included a shift in terms of content towards documentary and infotainment, both of which require lower budgets than movie production. An increasing number of productions were also moved to cheaper locations such as Berlin or Leipzig or were now produced by subcontractors and in cooperation with, for instance, Eastern European partners, in order to achieve cost advantages. That apart, the newly achieved independence permitted access to new clients and thus enabled an escape from the rigid constraints of the Kirch empire.

Field evidence suggests, however, that the networks of personal contacts in the industry persisted by and large, or even became strengthened over the crises period, as both new entrants as well as experienced agents observed:

It was very uncommon when we, as young producers, entered the tight market with the desire to produce commercial entertainment. Nobody was keen to get to know new people as everybody was just trying to keep the old boys' network alive. But then we saw our chance lying exactly in this restructuring of the old system which had no future anyway. We had to attract the people through more work, creativity and better ideas - that was our plan. (Film producer FP6, August 2007)

No doubt, our relationship with those guys [at ProSiebenSat.1] is much better than their relationship with their new shareholders. When such a financial investor tries to talk to them, he will not get through, whereas when we talk to them we do get through, because our relationship is based on trust. (Broadcaster BC1, August 2007)

On one hand, these observations illustrate the substantial tensions and the potential for agency problems at the interface between the two distinct business systems of the financial investor and its target company. On the other hand, they highlight the extent to which the institutional particularities of a cluster, such as the common identity and the sharing of views, are still maintained in Munich's film and TV industry and that the commitment and coherence previously developed prevail in the industry. That is, the trajectory of the cluster is observably marked by junctures of this nature, where persistent local paths interact with new dynamics at the local and the global scale.

11 Correspondingly, the share of the production volume (in minutes) for dependent producers decreased from the afore-mentioned figure of $50 \%$ to $32 \%$ and $34 \%$, respectively for 2003 and 2004 (Formatt, 2005). 


\subsection{Situating the restructuring of the industry in the wider context of the region}

As regards the cumulative effects of the adjustment processes within the film and TV industry on Munich's regional economy as a whole, a first important point to make is the gaining role of certain market niches, which were less well developed during the Kirch era, but developed only in the paradigm of global finance. First, a number of firms could have been established that became leading European addresses for international co-productions of specific television programs and formats (e.g. miniseries). ${ }^{12}$ With English language productions addressing themes, which are aimed to be commercially viable not only in Germany, but also in, for example, Italy, Japan and North America, and funding arrangements that usually include a variety of foreign partners, these firms have strengthened the international orientation of the location. Furthermore, the IPTV market ${ }^{13}$ and the games sector ${ }^{14}$, that is, the digitalisation-driven and technology oriented parts of the industry, experienced considerable growth. As a result, Munich is today acknowledged as one of the leading technological centres of the media industry in Germany.

A contributing factor to this development and the technological prominence has been the availability of venture capital. In addition to the overall attractiveness of Munich for venture capital and risk investors, as one of Germany's most important financial centres, several former Kirch executives who were very successful during the boom of the 1990s established investment companies with a specific focus on media technologies. To overcome the lack of available finance in the immediate postbankruptcy years, they played a significant role in terms of catalysing new commercial ideas. That is, the rise and entry of new financial agents has allowed escaping from former constraints, an observation which again demonstrates the ambivalent outcomes of financialisation. Not least, these investors contributed to set up new collaborations and thus potential constellations of learning, as the following explanation of one of the interviewed venture capitalists indicates:

We were not able to make [Firm X] take-off in 2003 - this was a very difficult time - as we could not find a financier. Not one. But then I went to Firm Y [another venture firm in Munich], with which I already had a well-established relationship. I told them: 'Trust me, I believe in these guys, they are able to do it and there is a niche in the market as well'. Then I said: 'If you join, I will then look for additional investors.' Later, when the investment was established and the task was to foster its growth requiring a second round of financing, their network helped to get Firm Z [a third venture capital firm] from Paris into the boat. They already knew each other from two or three other projects they had done together. (Investor IN4, August 2007)

12 Among the prominent examples of new, internationally oriented companies are Tandem Communications, founded by two former ProSieben executives, and Bavariapool International Coproductions, established in 2007 as subsidiary of Bavaria and Telepool, each holding 50\%.

13 IPTV is a system where a digital television service is delivered using Internet Protocol (IP) over a network infrastructure, which includes delivery by a broadband connection.

14 Not least, ProSiebenSat.1 itself has intensified its activities in the games segment and in 2007 agreed on cooperation with US producer ZeniMax. Since the acquisition of SBS, ProSiebenSat.1 holds a $\sim 9 \%$ minority stake in ZeniMax. 
Stimuli to pool different agents also came from the local banks that remained in the market. Driven by the incentive to serve potential future customers, they have since provided free-of-charge advisory services including the offer to introduce young producers, such as the graduates from Munich's University for Television and Film HFF, to more established, financially sound production companies. Within the framework of this so-called 'Patronatsmodell' producers can, in the event of a successful introduction, develop their project ideas as junior partners, in return for either a fee or shares in the company. ${ }^{15}$ During fieldwork, new-generation interviewees conceded an increasingly open attitude towards external funding and the inclusion of strategic partners, providing evidence that the traditionally rather sceptical attitude towards co-determination is softening more and more within the industry. Through this means, a number of today's successful, internationally oriented companies were able to be established, in some cases, even at the expense of retaining only a minority stake (compare also Figure 3, again).

All in all, the dissolution of the Kirch Group forced the full range of agents in the local media market - from former Kirch units and established companies, to banks and entrepreneurs - to rethink their business strategies and to open themselves up to innovative marketing and financial models. The resulting emergence of new configurations and learning situations rejuvenated Munich's film and TV industry and produced new relations within the regional, national and international arenas. Even though for certain parts of the industry, particularly, the former Kirch units including the ProSiebenSat.1 Group, the situation remains extremely tense within the control of financial investors, overall, the crisis and the entry of new players has in the meantime been widely acknowledged for its beneficial market-adjustment forces.

Notwithstanding all the short- or long-term forces of financial institutions, the most important factors for running a successful business within a cultural industry remain ideas and creativity. Thus, the challenge is to further develop and implement financing models that allow the creative potential of industrial entrepreneurs to be realised - a mission which is demanding not only in economical, but also in social and cultural terms. Given the shortage of bank liquidity and the increased costs of capital at the present, the international industry concedes that in the current climate 'with credit tighter than a Jason Bourne action sequence... and equity investors now a rare breed' (Masters and Kemp, 2009) film financing might require new approaches. Having just emerged from a painful restructuring, those who survived in Munich's film and TV industry are likely to be more case-hardened and better placed to handle the challenges presented by the current crisis.

\section{Conclusions}

This article has addressed the role of financial capital in relation to the development of a regional industry cluster. In doing so, it has revealed that the association between a local economy's integration into the global capitalist system, and its development performance is less straightforward than the current public and political arguments concerning the effects of financialisation and new financial agents might pretend.

15 In co-financed productions, in contrast, the partners involved provide capital in exchange for a portion of the profits and movie rights. 
Drawing on the case of Munich's film and TV industry following the crisis related to the insolvency of the Kirch Group in 2002, this research contributes to the literature on cluster development in two main ways. As a start, and most simply, the results demonstrate the extent to which changing ownership and the entry of financial investors such as KKR/Permira may cause immediate harmful effects to the companies involved and to their surroundings, thus supporting the prevalent suspicion of external control and the short-term profit orientation of certain players in contemporary financialised capitalism.

In addition, the research exemplifies the cumulative effects of new financialised practices within the specific fabric of an industry cluster. The investigation revealed the extent to which, in this particular case, the industry has indeed benefited from the impetus created by new financial investors, most notably the turnaround under Haim Saban, through the initiation of new learning constellations, the encouragement of a stronger international orientation and the creation of new, alternative, industryspecific financial instruments. That is, financialised practices provided the means to break out of the locked-in modes of productions within Munich's particular institutional arrangements during the Kirch era. They set in train moves to foster entrepreneurship, including greater openness to new means of finance such as the indicated Patronatsmodell, and resulted in a more diversified situation today. In this regard, it is important to place the impact of the restructuring of the industry into the wider context of the development of the region. In the present case, the dissolution of the Kirch Group and the investments of financial agents in the local broadcasting corporation not only affected the film and TV market, but the consequential restructuring also contributed to a collateral reinforcement of the whole location, including a strengthening of both the local financial sector and internet/new media segments.

Taken together, this study of Munich's film and TV industry illustrates the extent to which an examination of the complexity of the development consequences of financialised capitalism adds to our understanding of the development of regional clusters. Reconstituted financial structures and ownership relations either immediately emerge as value creating, to the extent that these changes encourage new investments, new actor constellations and new growth opportunities in previously less prominent technologies, or they strain a local economy and also its social cohesion. However, even in the latter case, the immediate effects must be contrasted against the longerterm, cumulative benefits which may result from these pressures, such as the re-grouping of existing unique skills and resources, better access to external sources of knowledge and, not least, a greater ability to foster linkages around the globe. In other words, while financialisation doubtlessly implies harmful adjustment processes due to an increased focus on shareholder value and the requirements of the global capitalist system, it may at the same time support — at least in an environment of general economic strength, as it is the case in Munich - the renaissance of traditional economic virtues such as entrepreneurial spirit, greater risk taking and increased innovative power. Note, however, that these impacts are highly context specific; supposedly, the positive effects observed here may occur only in rather successful regions in the global economy core, while for less well endowed regions other results should be expected.

Irrespective of this context-related ambiguity, the present case circumstantiates that financialisation does not necessarily imply convergence towards an Anglo-American style of capitalism. Instead, the emergence of financialised modes of operation goes 
hand in hand with new institutional paths and hybrid configurations. This is related to the fact that the trajectory of a cluster is marked by multiple junctions and the interaction of dynamic local and global developments. The study of financial practices and relations provides a promising approach to the untangling of these junctions and interactions. In this sense, money not only flows like mercury, but can also be regarded representing a mercury - in the sense of a messenger-for knowledge, ideas and creativity within clusters and beyond, tracing valuable paths to be further followed.

\section{Acknowledgements}

The author wishes to thank the interviewed executives and experts in and around the Munich film and TV industry for the time they devoted to the project. Furthermore, he is grateful to all students participating in his advanced exercise course on Munich's media cluster in summer 2007 and particularly Jonas König for excellent research assistance. Comments from Martin Hess, Matthias Kiese, Carsten Peter, Matthias Wallisch, the participants of the financial geographies session series at the 2008 AAG in Boston, three anonymous reviewers and the editors significantly helped to improve the focus of the paper. Of course, the author remains solely responsible for the arguments put forward.

\section{Funding}

This work was supported by the German Research Foundation DFG (grant ZA 591/1-1).

\section{References}

Alessandrini, P. and Zazzaro, A. (1999) A possibilist approach to local financial systems and regional development: the Italian experience. In R. Martin (ed.) Money and the Space Economy, pp. 71-91. Chichester: Wiley.

Asheim, B. T. and Herstad, S. J. (2003) Regional innovation systems and the globalising world economy. Discussion paper, SPACES 2003-12. Universität Marburg.

Bassett, K., Griffiths, R., Smith, I. (2003) Cultural industries, cultural clusters and the city: the example of natural history film-making in Bristol. Geoforum, 33: 165-177.

Bathelt, H. (2005) Geographies of production: growth regimes in spatial perspective (II) knowledge creation and growth in clusters. Progress in Human Geography, 29: 204-216.

Bathelt, H. and Boggs, J. S. (2003) Towards a reconceptualization of regional development paths: is Leipzig's media cluster a continuation of or a rupture with the past? Economic Geography, 79: 265-293.

Bathelt, H. and Gräf, A. (2008) Internal and external dynamics of the Munich film and TV industry cluster, and limitations to future growth. Environment and Planning A, 40: 1944-1965.

Bathelt, H., Malmberg, A., Maskell, P. (2004) Clusters and knowledge: local buzz, global pipelines and the process of knowledge creation. Progress in Human Geography, 28: 31-56.

BBC (2002) Media giant falls back to earth. British Broadcasting Corporation. Available at: http://news.bbc.co.uk/2/hi/business/1912978.stm.

Boschma, R. (2005) Proximity and innovation: a critical assessment. Regional Studies, 39: 61-74.

Chapman, K. (2003) Cross-border mergers/acquisitions: a review and research agenda. Journal of Economic Geography, 3: 309-334.

Christopherson, S. (2002) Why do national labour market practices continue to diverge in the global economy? The 'missing link' of investment rules. Economic Geography, 78: 1-20.

Clark, G. L. and Wójcik, D. (2005) Path dependence and financial markets: The economic geography of the German model, 1997-2003. Environment and Planning A, 30: 1769-1791. 
Clark, G. L. and Wójcik, D. (2007) The Geography of Finance: Corporate Governance in a Global Marketplace. Oxford: Oxford University Press.

Clevé, B. (1997) Wege zum Geld: Film-, Fernseh- und -Finanzierungen. Gerlingen: Bleicher Verlag.

Coe, N. M. (2000) The view from out West: embeddedness, inter-personal relations and the development of an indigenous film industry in Vancouver. Geoforum, 31: 391-407.

Cooke, P. (2002) Regional innovation systems: general findings and some new evidence from biotechnology clusters. Journal of Technology Transfers, 27: 133-145.

Dixon, A. D. and Monk, A. H. B. (2008) The power of finance: global influence with local differences. Available at: http://ssrn.com/abstract=1265635 [Accessed 29 October 2008].

Dore, R. (2008) Financialization of the global economy. Industrial and Corporate Change, 17: $1097-1112$.

Engelen, E. (2003) The logic of funding European pension restructuring and the dangers of financialisation. Environment and Planning A, 35: 1357-1372.

Engelen, E. (2007) 'Amsterdamned'? The uncertain future of a financial centre. Environment and Planning A, 39: 1306-1324.

Engelen, E. and Konings, M. (Forthcoming) Financial capitalism resurgent: comparative institutionalism and the challenges of financialization. In G. Morgan, J. L. Campbell, C. Crouch, P. H. Kristensen, O. K. Pedersen, R. Whitely (eds) Oxford Handbook of Comparative Institutionalism. Oxford: Oxford University Press.

Engelen, E., Konings, M., Fernandez, R. (2008a) Financialization and institutions. Lessons from the Dutch case. Paper presented at the Annual Meeting of the AAG, April 15-19, Boston, Massachusetts.

Engelen, E., Konings, M., Fernandez, R. (2008b) The rise of activist investors and patterns of political responses: lessons on agency. Socio-Economic Review, 6: 611-636.

Epstein, G. A. (ed.) (2005) Financialization and The World Economy. Cheltenham: Edward Elgar.

Ernst \& Young (2006) Filmbarometer 2006: Berlin, Hamburg, Köln, Leipzig, München und Rhein/Main: Stimmungen und Trends, Munich: Ernst \& Young.

Faulconbridge, J. R. (2007) London and New York's advertising and law clusters and their networks of learning: relational analyses with a politics of scale? Urban Studies, 44: 1635-1656.

Folkmann, P., Froud, J., Sukhdev, J., Williams, K. (2007) Working for themselves? Capital market intermediaries and present day capitalism. Business History, 49: 552-572.

Formatt (2005) Fernseh- und Filmproduktionsmarkt Deutschland 2003 und 2004. Forschungsprojekt im Auftrag der Staatskanzlei NRW. Dortmund: Formatt-Institut.

Froud, J., Haslam, C., Sukhdev, J., Williams, K. (2000) Shareholder value and financialization: consultancy promises, management moves. Economy and Society, 29: 80-110.

Froud, J. and Williams, K. (2007) Private equity and the culture of value extraction. New Political Economy, 12: 405-420.

Gertler, M. S. (2004) Manufacturing Culture: The Institutional Geography of Industrial Practice. Oxford: Oxford University Press.

Gibbon, P. (2002) At the cutting edge? Financialisation and UK clothing retailers: global sourcing patterns and practices. Competition \& Change, 6: 289-308.

Glassmann, U. (2008) Beyond the German model of capitalism: unorthodox local business development in the Cologne Media industry. European Planning Studies, 16: 465-486.

Gräf, A. (2005) München in der Krise? Projektorganisation und Wachstumsprobleme in der Film- und Fernsehproduktion - eine mehrdimensionale Clusterstudie. Discussion paper, SPACES 2005-8. Universität Marburg.

Hall, P. and Soskice, D. (2001) Varieties of Capitalism. Oxford: Oxford University Press.

Hellmann, T. and Puri, M. (2000) The interaction between product market and financing strategy: the role of venture capital. Review of Financial Studies Volume, 13: 959-984.

IHK (2007) IuK- und Medienstandort München 2007. Munich: IHK für München und Oberbayern und Landeshauptstadt München.

IHT (2007) Leo Kirch's comeback. International Herald Tribune, 26 September 2007.

Kaiser, R. and Liecke, M. (2007) The Munich feature film cluster: the degree of global integration and explanations for its relative success. Industry and Innovation, 14: 385-399.

Kiefer, M.-L. (2003) Medienökonomie und medientechnik. In K.-D. Altmeppen and M. Karmasin (eds) Medien und Ökonomie: Soziologie, Kultur, Politik, Philosphie, 
International, Geschichte, Technik, Journalistik, pp. 81-208. Wiesbaden: VS Verlag für Sozialwissenschaften.

Klagge, B. (2004) Finanzstandort Deutschland im Wandel? Rolle und Entwicklung des deutschen Risikokapitalmarktes. Petermanns Geographische Mitteilungen, 148: 18-25.

Klagge, B. and Martin, R. (2005) Decentralised versus centralised financial systems: is there a case for local capital markets? Journal of Economic Geography, 5: 387-421.

Krätke, S. (2002) Network analysis of production clusters: the Potsdam/Babelsberg film industry as an example. European Planning Studies, 10: 27-54.

Krippner, G. R. (2005) The financialization of the American economy. Socio-Economic Review, 3: $173-208$.

Kurp, M. (2004) Filmförderung erreicht Rekord-Niveau. Available at: http://www. medienmaerkte.de/artikel/kino/040502_film_foerderung.html [Accessed 15 September 2008].

Leyshon, A. and Thrift, N. (1997) Money/Space: Geographies of Monetary Transformation. London: Routledge.

Leyshon, A. and Thrift, N. (2007) The capitalisation of almost everything. Theory, Culture \& Society, 24: 97-115.

Malmberg, A. and Maskell, P. (2006) Localized learning revisited. Growth and Change, 37: 1-18.

Martin, R. and Sunley, P. (2006) Deconstructing clusters: chaotic concept or policy panacea? Journal of Economic Geography, 3: 5-35.

Martin, R., Sunley, P., Turner, D. (2002) Taking risks in regions: the geographical anatomy of Europe's emerging venture capital market. Journal of Economic Geography, 2: 121-150.

Maskell, P. and Malmberg, A. (1999) Localised learning and industrial competitiveness. Cambridge Journal of Economics, 23: 167-185.

Masters, C. and Kemp, S. (2009): How recession proof is the industry? Money is available, but financial crisis forces creativity, THR Digital Edition, 6 February 2009.

Milberg, W. (2008) Shifting sources and uses of profits: sustaining US financialisation with global value chains. Economy and Society, 37: 420-451.

Monk, A. H. B. (2009) The financial thesis: reconceptualizing globalisation's effect on firms and institution. Competition \& Change, 13: 51-74.

Mossig, I. (2004a) The networks producing television programmes in the Cologne Media Cluster (Germany): New firm foundation, flexible specialisation and efficient decision-making structures. European Planning Studies, 12: 155-171.

Mossig, I. (2004b) Standort und Produktionssystem in den Medienclustern München und Köln. Das Beispiel der Produktion von TV-Sendungen. Working Paper, Studien zur Wirtschaftsgeographie. Universität Giessen.

Mossig, I. (2008) Global networks of the motion picture industry in Los Angeles/Hollywood using the example of their connections to the german market. European Planning Studies, 16: $43-59$.

NYT (2003) A billionaire is close to deal for TV assets of KirchMedia. The New York Times, 17 March 2003.

NZZ (2006) Die neuen Dunkelmänner. Kritisch beäugte Finanzgesellschaften im Mediensektor. Neue Zürcher Zeitung, 24 November 2006.

O'Neill, P. (2001) Financial narratives of the modern corporation. Journal of Economic Geography, 1: 181-199.

Pike, A. (2005) 'Shareholder value' versus the regions: the closure of the Vaux Brewery in Sunderland. Journal of Economic Geography, 6: 201-222.

Pollard, J. S. (2003) Small firm finance and economic geography. Journal of Economic Geography, 3: 429-452.

Pollard, J. S. (2007) Making money, (re)making firms: microbusiness financial networks in Birmingham's Jewellery Quarter. Environment and Planning A, 39: 378-397.

Powell, W. W., Koput, K., Bowie, J., Smith-Doerr, L. (2002) The spatial clustering of science and capital: Accounting for biotech firm-venture capital relationships. Regional Studies, 36: 291-305.

Private Equity Online (2008) Global news and comment on private equity online. Available at: http://www.privateequityonline.com [Accessed 24 October 2008].

Saxenian, A. (1994) Regional Advantage: Culture and Competition in Silicon Valley and Route 128. Cambridge: Cambridge University Press. 
Schamp, E. W. (2003) Knowledge, innovation and funding in spatial context: the case of Germany. In A. Thierstein and E. W. Schamp (eds) Innovation, Finance and Space, pp. 179-193. Frankfurt: Department of Economic and Social Geography, University Frankfurt.

Scott, A. J. (2002) A new map of Hollywood: the production and distribution of American motion pictures. Regional Studies, 36: 957-975.

Shandley, R. R. (1999) Dismantling the dream factory: the film industry in berubbled Germany. German Studies Today, 16: 104-117.

Thierstein, A. (2003) Financial places, regional production system, and the gap to bridge: considerations for a research agenda. In A. Thierstein and E. W. Schamp (eds) Innovation, Finance and Space, pp. 197-214. Frankfurt: Department of Economic and Social Geography, University Frankfurt.

Tickell, A. (2000) Finance and localities. In G. L. Clark, M. P. Feldman, M. Gertler (eds) The Oxford Handbook of Economic Geography, pp. 230-247. Oxford: Oxford University Press.

Williams, K. (2000) From shareholder value to present-day capitalism. Economy and Society, 29: $1-12$.

Wójcik, D. (2006) Convergence in corporate governance: evidence from Europe and the challenge for economic geography. Journal of Economic Geography, 6: 639-660.

Woldt, R. (2002) Pay-TV: marktbereinigung auf breiter front. Media Perspektiven, 33: 534-543.

Zeller, C. (2003) Innovationssysteme in einem finanzdominierten AkkumulationsregimeBefunde und Thesen. Geographische Zeitschrift, 91: 133-155.

Zook, M. (2002) Grounded capital: venture financing and the geography of the internet industry, 1994-2000. Journal of Economic Geography, 2: 151-177. 